\title{
Fair and Equitable Treatment and Investor's Due Diligence Under International Investment Law
}

\author{
Yulia Levashova ${ }^{1,2}$ \\ Published online: 3 August 2020 \\ (c) The Author(s) 2020
}

\begin{abstract}
The investor's due diligence has become a significant factor in determining whether the legitimate expectations of an investor give rise to protection under the FET standard. This is especially relevant when an investor's claim for the protection of its legitimate expectations is based on the stability of a regulatory framework. The investor's due diligence in the context of the FET standard goes beyond the riskbased business due diligence performed by a foreign investor for its own benefit. It has implications for a state's right to regulate in the public interest and a broader notion of business responsibilities. Investors are expected to conduct proper due diligence before investing in a host state by demonstrating their reasonable efforts to collect information about the rules and regulations that are pertinent to the proposed investment. In some cases, due diligence extends to an investor's duty to assess the possible risks related to the broader economic situation and socio-political background of a host state. Focusing on the recent renewable energy awards, this article analyses and clarifies the role of due diligence in the context of the FET standard, as well as its potential application for asserting responsible business conduct in the broader framework of international investment law.
\end{abstract}

Keywords IIAs $\cdot$ FETs $\cdot$ Due diligence $\cdot$ FDI $\cdot$ Investment law

\section{Introduction}

Tribunals are increasingly referring to an investor's duty to exercise due diligence in investment arbitral decisions. In some cases, tribunals even provide that exercising due diligence is necessary in order for an investor to have his legitimate expectations protected under the fair and equitable treatment (FET) standard. This development

Yulia Levashova

j.levashova@nyenrode.nl

1 Nyenrode Business University, Breukelen, The Netherlands

2 Utrecht University, Utrecht, The Netherlands 
forms part of the balancing efforts recently undertaken by tribunals in weighing the host state's right to regulate against the legitimate expectations of an investor.

The investor's due diligence in the context of the FET standard goes beyond the risk-based business due diligence performed by a foreign investor for his own benefit. It has implications for a state's right to regulate in the public interest and a broader notion of business responsibilities. Investors are expected to conduct proper due diligence before investing in a host state by demonstrating their reasonable efforts to collect information about the rules and regulations that are pertinent to the proposed investment. In some cases, due diligence extends to an investor's duty to assess the possible risks related to the broader economic situation and sociopolitical background of a host state. The goal of this article is to analyse the role of due diligence in the context of the FET standard, as well as to assess its potential application for asserting responsible business conduct in the broader framework of international investment law.

The article will proceed in the following order. Firstly, the application and the interpretation of the legitimate expectations of an investor as one of the central elements of the FET standard will be briefly outlined. Secondly, the role of due diligence is discussed with the example of recent energy disputes. Thirdly, the article will address how a due diligence tool can be used by tribunals to ensure predictability and consistency in balancing the legitimate expectations of an investor under the FET standard and the state's right to regulate. Several final remarks will be offered at the end of the article.

\section{Legitimate Expectations in International Investment Law}

One of the central pillars of investment protection under international law is the understanding that a foreign investor investing in a host state should be treated fairly and equitably. The importance of this notion is supported by the inclusion of the FET standard in most International Investment Agreements (IIAs), as well as its invocation in the vast majority of investment disputes. The protection of legitimate expectations is the central component of the FET standard. ${ }^{1}$

The concept of legitimate expectations is well known in a number of domestic legal systems, and has been recognised in both public international law and European law. ${ }^{2}$ In international investment law, the concept of the legitimate expectations of an investor became a prominent element of the fair and equitable treatment in the early 2000s.

In CME v. Czech Republic ${ }^{3}$ - one of the early decisions on the FET standard that was delivered in 2001- the tribunal indirectly referred to legitimate expectations in

\footnotetext{
1 Levashova (2019), p. 113.

2 Brown (2009), p. 1.

${ }^{3}$ CME v. Czech Republic, UNCITRAL case, Award, 14 March 2003.
} 
its decision. A few years later, in the Tecmed v. Mexico award of $2003,{ }^{4}$ the tribunal assessed whether legitimate expectations had to lead to the protection of the investor under the FET standard. ${ }^{5}$ Since then, this legal concept has developed and evolved in many international investment cases. ${ }^{6}$ Currently, assessing the protection of the legitimate expectations of an investor constitutes a central element of the FET standard evaluation in the majority of FET investment cases. ${ }^{7}$ In this vein, it is important to note that the investor's legitimate expectations are usually based on (1) a specific representation made by the host state to an investor regarding its investment, or (2) an assumption on the part of the investor that the general regulatory framework relied upon by it at the time the investment was made will remain stable.

Specific representations can be provided to investors in different forms, e.g. in the host state's legislation or through contractual commitments. ${ }^{8}$ Usually, a foreign investor's claim of a breach of its legitimate expectations is based on changes or alterations to the original representation(s) made to that investor by the host state. The 'reversal of [representations] made by the host state that have led to legitimate expectations will violate the principle of fair and equitable treatment' ${ }^{9}$ The jurisprudence on the FET standard reveals that the level of specificity that is required by a tribunal varies from case to case. To determine whether the representations qualify as specific, tribunals will usually address three questions, namely: (1) whether the representations are created by a competent state authority; (2) what the legal force of the specific representation is in terms of its legal form, content and wording; and (3) how the investor has been designated in the state's representations. ${ }^{10}$ Following an

\footnotetext{
4 Técnicas Medioambientales Tecmed, S.A. v. United Mexican States, ICSID Case No. ARB(AF)/00/2, Award, 29 May 2003.

5 Sornarajah (2015), p. 257; Wongkaew (2015), p. 75.

6 Bonnitcha (2014), p. 20. The author states that 'since 2006, protection of the investor's legitimate expectations has emerged as the most significant element of the FET standard. The doctrine of legitimate expectations has been sufficiently widely accepted [...].' Sornarajah (2015), p. 257; Potestà (2013), p. 88 '[i]f one observes the awards given by investment treaty tribunals in the last few years, one will hardly find any example where the concept of "legitimate expectations" has not been invoked by the claimant [...]'.

7 Bonnitcha (2014), pp. 161-162. Bonnitcha summarises the history of the legitimate expectations doctrine in investment law as follows: 'Since 2006, protection of the investor's legitimate expectations has emerged as the most significant element of the FET standard. The doctrine of legitimate expectations has been sufficiently widely accepted that arbitral decisions now spend more time examining the contours of the doctrine than determining whether compliance with the doctrine is an element of FET. This shared recognition of legitimate expectations as an element of FET is reflected in academic commentary.' Laird et al. (2015), p. 105. Reviewing the decisions on the FET standard rendered in 2013, the authors emphasised that 'tribunals in 2013 recognized that the protection of the claimant's legitimate or reasonable expectations is a well-accepted component of the FET standard'.

8 Suez, Sociedad General de Aguas de Barcelona, S.A. and Vivendi Universal, S.A. v. Argentine Republic, ICSID Case No. ARB/03/19, Decision on Liability, 30 July 2010, para. 222. The tribunal explained that 'when an investor undertakes an investment, a host government through its laws, regulations, declared policies, and statements creates in the investor certain expectations about the nature of the treatment that it may anticipate from the host State'.

9 Dolzer and Schreuer (2014), p. 145.

${ }^{10}$ Levashova (2019), pp. 123-139. This study provides an extensive analysis of specific representations on the basis of numerous cases.
} 
analysis of this jurisprudence, several important observations can be made. Firstly, in several decisions, the tribunals have clarified that the state's representations can only be regarded as specific if they were provided by a competent state authority that has the relevant decision-making power. ${ }^{11}$ Secondly, in analysing the legal form, content and wording of a representation, tribunals have emphasised that in order to qualify as specific, a representation should have a formal character and should be aimed at the purposeful and specific inducement of an investment. ${ }^{12}$ In some decisions, it has been underlined that the specific promise should be expressed as an explicit commitment. ${ }^{13}$ Thirdly, tribunals have been consistent in ruling that the state's representations should be addressed directly to a particular investor and cannot be aimed at large or even small groups of potential investors.

In the absence of any specific representations by the host state to the investor, or in addition thereto, the investor can still have legitimate expectations, i.e. the expectation of the stability of the general legal framework. ${ }^{14}$ Under the concept of legitimate expectations in international investment law, states are required to maintain a certain degree of stability and predictability in their regulatory framework as this is relied upon by investors when making investments. ${ }^{15}$ Tribunals have considered there to be a breach of an investor's legitimate expectations where a host state makes substantial subsequent changes to the legal framework that were effective at the time when the investment was made, and which have resulted in serious financial losses being suffered by the investor or in the inability of the investor to continue operating its investment. ${ }^{16}$

The state's right to regulate plays a central role in determining the limits of the protection of the investor's legitimate expectations. Whether the investor makes a claim for the protection of its legitimate expectations on the ground of a reversal of a specific representation made to it by the host state, or on the basis of a substantial change to the general regulatory framework, in both situations it will refer to the state's regulatory and/or administrative conduct, e.g. the change which the state has made to the law, or the revocation of the licence in question.

The tension between the state's right to regulate and the protection of the legitimate expectations of an investor involves 'a state's insistence on its authority to adapt its rules to the public interest and an investor's insistence on a right to rely on a regime which induced it to invest'. ${ }^{17}$ Tribunals have attempted to resolve this

\footnotetext{
11 Metalclad Corporation v. United Mexican States, ICSID Case No. ARB(AF)/97/1, Award, 30 August 2000, para. 86; Crystallex International Corporation v. Bolivarian Republic of Venezuela, ICSID Case No. ARB(AF)/11/2, Award, 4 April 2016, paras. 561-562; Total v. Argentina, ICSID Case No. ARB/04/01, Decision on Liability, 27 December 2010, para. 121.

12 Glamis v. US [2009] NAFTA, ICSID 48 ILM 1039, Award, 8 June 2009, para. 766.

${ }^{13}$ Mamidoil Jetoil Greek Petroleum Products Société S.A. v. Republic of Albania, ICSID Case No. ARB/11/24, Award, 30 March 2015, para. 648; LG\&E Energy Corp., LG\&E Captial Corp. \& LG\&E International v. The Argentine Republic, ICSID Case No. ARB/02/1, Decision on Liability, 3 October 2006, para. 130.

14 Klager (2011), p. 164.

15 Vandevelde (2010), p. 66.

16 Valenti (2014), p. 41.

17 Paulsson (2016).
} 
tension by striving to reconcile the subjective interests of the investor deriving from its legitimate expectations and the state's right to regulate in the public interest. ${ }^{18}$

On the one hand, in general, tribunals' assessment of the legitimacy of expectations involves a review of the subjective interests of an investor in relation to the state's conduct. An important consideration in this assessment is the specific nature of a state's representations. ${ }^{19}$ In assessing the level of specificity, tribunals commonly review the legal force of the state's representations through their legal form, content, and wording, as explained above. The investor may reasonably expect that its expectations are legitimate if they are based on specific and unambiguous state representations. ${ }^{20}$ In contrast, in situations where an investor claims that its expectations have been frustrated because of changes implemented in the general regulatory framework, tribunals have clarified that such an investor cannot reasonably expect that the state will not amend its laws. ${ }^{21}$ Tribunals have thereby generally expressed the view that only serious changes to a regulatory framework-impacting the investor and its investment-may give rise to the protection of its legitimate expectations.

On the other hand, in assessing the legitimacy of expectations, tribunals evaluate factors that are independent from an investor's subjective interests. For example, they take into account certain special circumstances that were relevant to the investment. $^{22}$ This means that tribunals may attach importance to the economic and socio-political circumstances that influenced the state's measure. ${ }^{23}$ In assessing the investor's expectations, tribunals consider the economic and socio-political circumstances that have affected the reversal of the state's representations and which have interfered with the expectations of the investor. Examples of special economic and socio-political circumstances include an economic and/or financial crisis in the host state; the socio-political transition of former socialist countries; and the economic

\footnotetext{
18 As observed by Dupuy and Dupuy, who analysed the role of legitimate expectations in the FET standard, 'many arbitrators consider that it [the FET standard] creates a subjective right for each investor to have its expectations to be protected as far as these expectations are legally "legitimate".' This statement reflects the opinion of many international investment lawyers. As provided by Dupuy and Dupuy, the general idea of legitimate expectations, supported in different legal systems, is to provide a 'balance between the individual's private interest and the public interest represented by the state'. Dupuy and Dupuy (2015), p. 276. This is also reflected in investment jurisprudence, see: Saluka Investments BV v. Czech Republic [2006] UNCITRAL Arbitration Partial Award, 17 March 2006, para. 306. The tribunal provided that the review of the FET standard requires a 'weighing of the Claimant's legitimate and reasonable expectations on the one hand and the Respondent's legitimate regulatory interests on the other'. See also El Paso v. Argentina, ICSID Case No. ARB/03/15, Award, 31 October 2011, para. 358. The tribunal emphasised that 'legitimate expectations cannot be solely the subjective expectations of the investor $[\ldots]$ investor's legitimate expectations must be grounded in reality, experience and context'.

19 Wongkaew (2015), p. 99.

20 Total v. Argentina, ICSID Case No. ARB/04/01, Decision on Liability, 27 December 2010, para. 117; Duke v. Ecuador, ICSID Case No. ARB/04/19, Award, 18 August 2008, para. 351.

21 El Paso v. Argentina, ICSID Case No. ARB/03/15, Award, 31 October 2011, para. 374; Ioan Micula v. Romania, ICSID Case No. ARB/05/20, Final Award, 11 December 2013, para. 673.

22 In the words of the Saluka decision, the legitimate expectations doctrine does not just protect the subjective expectations of an investor; they 'must rise to the level of legitimacy and reasonableness in the light of circumstances'. Saluka Investments BV v. Czech Republic [2006] UNCITRAL Arbitration Partial Award, 17 March 2006, para. 304.

23 Duke Energy v. Ecuador, ICSID Case No. ARB/04/19, Award, 18 August 2008, para. 340.
} 
deficit challenge in the renewable energy sector. These special, public interest circumstances are considered relevant by tribunals in deciding on the protection of the legitimate expectations of an investor. Tribunals have provided that in a situation of economic crisis or a socio-political transition, an investor cannot expect that the state will act as it would do in normal circumstances. The reversal of some of the state's representations interfering with the expectations of an investor has been justified on the basis of a public interest measure adopted to remedy the consequences of the crisis or the post-transition period. At the same time, a host state's response to the crisis cannot be justified if it is disproportionate to the impact of such measures on the investment. ${ }^{24}$ Where (1) the key features of the state's regulatory framework which has been relied upon by the investor are eliminated; and (2) the investor suffers a serious financial loss, the tribunal is more likely to conclude that the FET standard has been violated. ${ }^{25}$ The question of the extent to which a state can regulate in order to respond to special circumstances without violating the FET standard depends on elements such as how severe the crisis is, whether the state has provided specific representations to the investor, as well as whether the investor has performed a proper due diligence investigation.

The investor's due diligence has been considered a relevant factor for tribunals in deciding whether an investor's expectations can be considered legitimate and therefore protected. ${ }^{26}$ This article considers, in particular, the content of an investor's due diligence and the scope of this requirement by analysing investment jurisprudence, with a special focus on a number of recent decisions concluded in $2019 .{ }^{27}$

\section{The Due Diligence of an Investor in FET Cases}

The investor's due diligence is a factor that has been emphasised by tribunals in determining whether the expectations of an investor are legitimate and can give rise to protection under the FET standard. In Saluka v. Czech Republic (2006), for the first time the tribunal clearly articulated limitations on the protection of the investor's legitimate expectations by providing that 'expectations in order to be protected, must rise to the level and reasonableness in light of circumstances' ${ }^{28}$ To determine

\footnotetext{
${ }^{24}$ Antin Infrastructure Services Luxembourg S.à.r.l. and Antin Energia Termosolar B.V. v. Kingdom of Spain, ICSID Case No. ARB/13/31, Award, 15 June 2018, para. 556; Blusun S.A., J.-P. Lecorcier and M. Stein v. Italy, ICSID Case No. ARB/14/3, Award, 27 December 2016, para. 319.

${ }^{25}$ Eiser Infrastructure Ltd. and Energia Solar Luxembourg v. Spain, ICSID Case No. ARB/13/36, Award, 4 May 2017, para. 365.

${ }^{26}$ Viñuales (2017), p. 362.

${ }^{27}$ Stadtwerke München v. Spain, ICSID Case No. ARB/15/1, Award, 2 December 2019; OperaFund Eco-Invest v. Spain, ICSID Case No. ARB/15/36, Award, 6 September 2019; SolEs Badajoz v. Spain, ICSID Case No. ARB/15/38, Award, 31 July 2019; Belenergia v. Italy, ICSID Case No. ARB/15/40, Award, 6 August 2019; CEF Energia BV v. Italy, SCC Case No. 158/2015, Award, 16 January 2019; Cube Infrastructure Fund SICAV and others v. Kingdom of Spain, ICSID Case No. ARB/15/20, Award, 26 June 2019.

${ }^{28}$ Saluka Investments BV v. Czech Republic [2006] UNCITRAL Arbitration Partial Award, 17 March 2006, para. 304.
} 
the reasonableness of an investor's expectations, the circumstances that are pertinent to an investment-including an investor's conduct-have to be considered. Following the same line of reasoning, numerous tribunals have provided that in order to assess the reasonableness or legitimacy of an investor's expectations, one should consider the efforts undertaken by an investor in performing its due diligence before investing in a host state. This due diligence factor has featured specifically in the context of an investor's claim relating to the stability of a regulatory framework. Investment tribunals have considered that an investor investing in a host state should be able to rely on a certain degree of stability relating to its investment. ${ }^{29}$ This does not however imply that investors should expect that the legal framework will not change at all. Tribunals have emphasised that a state's 'legal framework is by definition subject to change as it adapts to new circumstances day by day and a state has the sovereign right to exercise its powers which include legislative acts'. ${ }^{30}$ In assessing claims that are based on an investor's expectations concerning the stability of a general regulatory framework, tribunals have provided that such expectations can only be protected under certain limited conditions. For example, several tribunals underline that a change to the regulatory framework has to be drastic and/or discriminatory and has a substantial financial impact on the investor in order to come to the conclusion that the investor's legitimate expectations have been breached. ${ }^{31}$ Also, some tribunals have emphasised the significance of the way in which the state has transformed the general regulatory framework that has been relied upon by the investor. This implies that the changes should be proportional and must not lead to a 'sudden and unpredictable elimination of the essential characteristics of the existing framework' ${ }^{32}$ Tribunals have underlined that the state can change its regulatory framework, but it has to respect 'basic features' that are entrenched in the legal framework regulating the specific field or industry and which have been relied upon by an investor in making the investment in the first place. ${ }^{33}$

It follows that an assessment of whether an investor has undertaken due diligence at the time of making the investment serves as a limiting factor on the protection of an investor's expectations. The claim for the protection of an investor's expectations can be significantly reduced if the respondent state can demonstrate that the changes to a regulatory framework were foreseeable. For example, the tribunal in Biwater $v$.

\footnotetext{
29 Parkerings $v$. Lithuania, ICSID Case No. ARB/05/8 Award, 11 September 2007, para. 333. The tribunal provided that 'in principle, an investor has a right to a certain stability and predictability of the legal environment of the investment'.

${ }^{30}$ AES Summit v. Hungary, ICSID Case No. ARB/07/22, Award, 23 September 2010, para. 9.3.29. See also Parkerings v. Lithuania, ICSID Case No. ARB/05/8, Award, 11 September 2007, para. 333. See also Continental Casualty v. Argentina, ICSID Case No. ARB/03/9, Award, 5 September 2008, para. 258.

31 Toto v. Lebanon, ICSID Case No. ARB/07/12, Award, 7 June 2012, para. 244. See also El Paso v. Argentina, ICSID Case No. ARB/03/15, Award, 31 October 2011, para. 510.

32 Charanne Construction v. Spain, SCC Case No. V 062/2012, Final Award, 21 January 2016, para. 517; Antin Infrastructure Services Luxembourg S.à.r.l. and Antin Energia Termosolar B.V. v. Kingdom of Spain, ICSID Case No. ARB/13/31, Award, 15 June 2018, para. 556; Eiser Infrastructure Ltd. and Energia Solar Luxembourg v. Spain, ICSID Case No. ARB/13/36, Award, 4 May 2017, para. 370.

33 Total v. Argentina, ICSID Case No. ARB/04/01, Decision on Liability, 27 December 2010, para. 168. Charanne Construction v. Spain, SCC Case No. V 062/2012, Final Award, 21 January 2016, para. 539.
} 
Tanzania (2008) underlined that, in establishing a violation, "countervailing factors such as the responsibility of foreign investors, both in terms of prior due diligence as well as subsequent conduct' should be considered. ${ }^{34}$ It also observed that the legitimate expectations of an investor may be reduced 'in circumstances where an investor itself takes on risks in entering a particular investment environment'. ${ }^{35}$

This point was also made by the tribunal in Parkerings v. Lithuania (2007). The tribunal stated that considering the socio-political and economic transition in Lithuania, the investor should have anticipated changes to the regulatory framework. The tribunal provided that '[a]s any businessman would, the Claimant was aware of the risk that changes of laws would probably occur after the conclusion of the Agreement'. ${ }^{36}$ Therefore, the investor is expected to consider business risks, which to a large extent depend on the country in which the investment is being made. ${ }^{37}$ This point has been illustrated by Viñuales who has stated that it would not be reasonable for an investor investing in a highly volatile political environment, whatever the assurances received, that the investment will no longer affected by further disruptions, ${ }^{38}$

In Mamidoil v. Albania (2015), the tribunal supported the view that an investor has to demonstrate proper due diligence in order for its expectations to be protected. Such a diligent inquiry extends to an evaluation of the overall circumstances and an understanding of the content and the context of the law and administrative practice. In this case, a Greek company, Mamidoil (the investor), invested in Albania by constructing and operating an oil terminal in the port of Durrës. In order to do so, Mamidoil entered into a lease contract that leased land in the Durrës region for 20 years. However, in later years, the Albanian authorities wanted to relocate the project for environmental and socio-economic reasons. The investor initiated arbitration proceedings against Albania claiming a breach of the FET standard under the AlbaniaGreece Bilateral Investment Treaty (BIT). The investor argued that the change in the regulatory framework existed at the time of the investment and that its expectations, that were based on the specific representation, were frustrated because of the relocation of the project. The tribunal rejected both claims. The central factor in declining the protection of the investor's expectations arising out of stability was the lack of the investor's due diligence. As a starting point, the tribunal asserted that in order for an investor to rely on the stability and transparency of a legal framework, it

has to understand the content and the context of the law and the administrative practice. Put differently, the standard is addressed to both the State and the investor. Fairness and equitableness cannot be established adequately without an adequate and balanced appraisal of both parties' conduct. ${ }^{39}$

\footnotetext{
${ }^{34}$ Biwater v. Tanzania (2008), ICSID Case No. ARB/05/22, Final Award, 24 July 2008, para. 601.

35 Biwater v. Tanzania (2008), ICSID Case No. ARB/05/22, Final Award, 24 July 2008, para. 601.

36 Parkerings v. Lithuania, ICSID Case No. ARB/05/8 Award, 11 September 2007, para. 335.

37 Sureda (2012), p. 79.

38 Viñuales (2017), p. 363.

39 Mamidoil Jetoil Greek Petroleum Products Société S.A. v. Republic of Albania, ICSID Case No. ARB/11/24, Award, 30 March 2015, para. 634.
} 
In this case, the investor demonstrated that it had made no effort to conduct a diligent analysis of the regulatory framework, such as by requesting legal advice. The tribunal noted that the stance of the investor that it '[didn't] need a lawyer' was not acceptable, especially in the context of a transition economy like Albania. ${ }^{40}$ The tribunal expressly acknowledged the pivotal role of the hardship experienced by Albania that had 'just overcome a highly repressive and isolationist communist regime' and experienced a 'severe economic and financial crisis, which brought it to the brink of the complete collapse of its State structures' ${ }^{41}$ The tribunal explained that an investor could not expect that the legal framework at the time of the investment would remain stable, considering that the Albanian system was still rooted in communist traditions. This heritage of the host state and 'the overwhelming necessities of the present and future' were key factors considered in the tribunal's decision on legitimate expectations. ${ }^{42}$ In the same vein, the tribunal in the Urbaser $v$. Argentina $^{43}$ case emphasised that an investor should have known by conducting proper due diligence that Argentina has human rights obligations to provide water to its citizens. The Urabser tribunal in assessing a FET claim noted that an investor being a major shareholder in a water concession providing water and sanitation services to the people of Buenos Aires was expected to be aware of the important objective of the government 'to ensure the population's health and access to water' according to its Constitution. ${ }^{44}$ The tribunal emphasised: when 'measures had been taken that have as their purpose and effect to implement such fundamental rights protected under the Constitution, they cannot hurt the fair and equitable treatment standard because their occurrence must have been deemed to be accepted by the investor when entering into the investment and the Concession Contract'. ${ }^{45}$ In short, they were expected to be part of the investment's legal framework.

The requirement to assess the general investment climate is often tailored to specific circumstances that are relevant for a host state at the time of investment. For example, the majority of cases decided between 2016 and 2019 concerned the renewable energy sector. These cases clearly demonstrate the significance of an investor's due diligence in evaluating legitimate expectations. They also reveal discrepancies in relation to the level of due diligence required in cases with very similar sets of facts. In the following sub-section, the role and the scope of an investor's due diligence is analysed in recent renewable energy arbitrations conducted under the Energy Charter Treaty (ECT).

\footnotetext{
${ }^{40}$ Mamidoil Jetoil Greek Petroleum Products Société S.A. v. Republic of Albania, ICSID Case No. ARB/11/24, Award, 30 March 2015, para. 671.

${ }^{41}$ Mamidoil Jetoil Greek Petroleum Products Société S.A. v. Republic of Albania, ICSID Case No. ARB/11/24, Award, 30 March 2015, para. 625.

${ }^{42}$ Mamidoil Jetoil Greek Petroleum Products Société S.A. v. Republic of Albania, ICSID Case No. ARB/11/24, Award, 30 March 2015, para. 629.

43 Urbaser S.A. and Consorcio de Aguas Bilbao Bizkaia, Bilbao Biskaia Ur Partzuergoa v. The Argentine Republic, ICSID Case No. ARB/07/26, Award, 8 December 2016.

44 Urbaser S.A. and Consorcio de Aguas Bilbao Bizkaia, Bilbao Biskaia Ur Partzuergoa v. The Argentine Republic, ICSID Case No. ARB/07/26, Award, 8 December 2016, para. 622.

45 Urbaser S.A. and Consorcio de Aguas Bilbao Bizkaia, Bilbao Biskaia Ur Partzuergoa v. The Argentine Republic, ICSID Case No. ARB/07/26, Award, 8 December 2016, para. 622.
} 


\subsection{An Investor's Due Diligence in Renewable Energy Disputes}

Investment cases in the renewable energy sector have been steadily increasing since a number of states have reduced their incentive schemes for renewable energy producers due to financial and economic difficulties. ${ }^{46}$ Spain, Italy and the Czech Republic are among the respondent states that currently face investment claims because of alterations to their regulatory frameworks for renewable energy. ${ }^{47}$ These host states' changes to the regulatory renewable energy regimes were primarily motivated by an increasing electricity tariff deficit. The deficit resulted from the difference between the subsidies in the form of feed-in tariffs granted by these host states to producers of renewable energy and the tariffs that had to be paid by consumers. In the case of Spain, the situation worsened because of the global economic crisis experienced by Spain between 2008 and 2014. ${ }^{48}$ Despite the differences between the cases against Spain, Italy and the Czech Republic, the issue of the investors' due diligence in predicting the changes brought about by their respective governments through the elimination of subsidy schemes had been discussed by all tribunals. However, in all of the decisions the threshold of the due diligence required differed. In examining 13 recent energy disputes ${ }^{49}$ as well as earlier research on the subject, ${ }^{50}$ this article analyses the role and key features of the requirement for an investor to undertake due diligence.

\footnotetext{
46 Selivanova (2018), p. 435; Matteotti and Payosova (2017), pp. 428-456.

47 E.g. Antaris Solar GmbH and Dr. Michael Göde v. Czech Republic, PCA Case No. 2014-01, Award, 8
} May 2018; Natland and others v. Czech Republic, PCA Case No. 2013-35, Notice of Arbitration (2013); Masdar Solar \& Wind Cooperatief U.A. v. Kingdom of Spain, ICSID Case No. ARB/14/1, Award, 16 May 2018; CSP Equity Investment Sarl v. Kingdom of Spain, SCC Case No. 094/2013, Notice of Arbitration (2013); DCM Energy and others v. Kingdom of Spain, ICSID Case No. ARB/17/41, Notice of Arbitration (2017); Aharon Naftali Biram, and others v. Kingdom of Spain, ICSID Case No. ARB/16/17, Notice of Arbitration (2016); FREIF Eurowind v. Kingdom of Spain, SCC Case No. 2017/060, Notice of Arbitration (2017); Portigon AG v. Kingdom of Spain, ICSID Case No. ARB/17/15, Notice of Arbitration (2017); ESPF Beteiligungs GmbH and others v. Italian Republic, ICSID Case No. ARB/16/5, Notice of Arbitration (2016); Sun Reserve Luxco Holdings SRL v. Italy, SCC Case No. 132/2016; Eskosol S.p.A. in liquidazione v. Italian Republic, ICSID Case No. ARB/15/50, Notice of Arbitration (2015); Blusun S.A., J.-P. Lecorcier and M. Stein v. Italy, ICSID Case No. ARB/14/3, Award, 27 December 2016.

48 Bank of Spain (2017).

49 Charanne Construction v. Spain, SCC Case No. V 062/2012, Final Award, 21 January 2016; Antaris Solar GmbH and Dr. Michael Göde v. Czech Republic, PCA Case No. 2014-01, Award, 8 May 2018; Cube Infrastructure Fund SICAV and others v. Kingdom of Spain, ICSID Case No. ARB/15/20, Award, 26 June 2019; Novenergia v. Spain, SCC Case No. 2015/063, Final Award, 15 February 2018; Masdar Solar \& Wind Cooperatief U.A. v. Kingdom of Spain, ICSID Case No. ARB/14/1, Award, 16 May 2018; Stadtwerke München and others v. Spain, ICSID Case No. ARB/15/1, Award, 2 December 2019; Antin Infrastructure Services Luxembourg S.à.r.l. and Antin Energia Termosolar B.V. v. Kingdom of Spain, ICSID Case No. ARB/13/31, Award, 15 June 2018; Isolux Netherlands, BV v. Kingdom of Spain, SCC Case V2013/153, Award, 17 July 2016; SolEs Badajoz GmbH v. Kingdom of Spain, ICSID Case No. ARB/15/38, Award, 31 July 2019; Foresight v. Spain SCC Case No. 2015/150, Final Award, 14 November 2018.; OperaFund Eco-Invest v. Spain, ICSID Case No. ARB/15/36, Award, 6 September 2019; Belenergia v. Italy, ICSID Case No. ARB/15/40, Award, 6 August 2019; CEF Energia BV v. Italy, SCC Case No. 158/2015, Award, 16 January 2019.

${ }^{50}$ Levashova (2019), pp. 123-139. 
As will be demonstrated, the scope of the required due diligence depends on the extent of the foreseeability of changes at the time of the investment and the respective efforts undertaken by an investor to predict these changes. Tribunals typically assess the efforts of an investor according to (1) the form and the content of the conducted due diligence; and (2) the foreseeability of changes in a host state that could be predicted by a diligent investor with the information available to it. These two criteria are elaborated upon below.

\subsubsection{The Form and the Content of Due Diligence}

In this section, the question concerning whether tribunals determine any formal requirements in relation to the form and content of an investor's due diligence is examined. In a large number of cases, tribunals have required some sort of due diligence to be carried out, whether this is in the form of a legal opinion drafted by a law firm or a qualified advisor, or by virtue of some other evidence to suggest that an investor, being a professional, had taken reasonable efforts to analyse the regulatory framework. Legitimate expectations will be violated if 'the regulatory measures [...] [were not] been reasonably foreseeable at the time of investment'. ${ }^{51}$ In a small number of cases, tribunals have not required any specific form of due diligence by an investor.

Examples of this latter category can be found within three recent decisions against Spain: SolEs Badajoz v. Spain, Cube Infrastructure v. Spain and Novenergia $v$. Spain. In these cases, the role of the due diligence enquiry was limited. In SolEs Badajoz v. Spain and Cube Infrastructure v. Spain, the tribunals indicated that there was no requirement to conduct a formal due diligence process and that it cannot be considered a precondition to a successful claim for the protection of legitimate expectations. ${ }^{52}$ This being said, the tribunals nevertheless noted that some due diligence efforts are expected from an investor. In SolEs Badajoz v. Spain, the tribunal explained that a FET is an objective standard and an investor's expectations are measured according to the 'knowledge that a hypothetical prudent investor is deemed to have had as of the date of the investment'. ${ }^{53}$ Ultimately, the tribunal concluded that the investor had conducted adequate due diligence, having been aware of possible moderate changes. However, drastic changes that resulted in the replacement of the feed in tariffs (FiTs) scheme ${ }^{54}$ with a new regime providing only a reasonable rate of return had violated the FET of the investor. ${ }^{55}$

\footnotetext{
51 Charanne Construction v. Spain, SCC Case No. V 062/2012, Final Award, 21 January 2016, para. 505.

52 Cube Infrastructure Fund SICAV and others v. Kingdom of Spain, ICSID Case No. ARB/15/20, Award, 26 June 2019, para. 396; SolEs Badajoz GmbH v. Kingdom of Spain, ICSID Case No. ARB/15/38, Award, 31 July 2019, para. 331.

53 SolEs Badajoz GmbH v. Kingdom of Spain, ICSID Case No. ARB/15/38, Award, 31 July 2019, para. 331.

54 The special regime was created primarily by the way of enacting Royal Decree 661/2007, e.g., providing fixed tariffs for producers.

55 SolEs Badajoz GmbH v. Kingdom of Spain, ICSID Case No. ARB/15/38, Award, 31 July 2019, para. 462.
} 
In a similar vein, in Cube v. Spain the tribunal found that an investor's expectations that the state's reforms will not undermine the 'fundamental characteristics' of a regulatory regime based on Royal Decree 661/2007 were protected. The respondent state emphasised that the claimant had not undertaken any due diligence regarding the regulatory framework. The tribunal found that the investor's right to rely on the protection of its expectations 'does not depend on there being evidence of any particular form or scale of legal due diligence by external advisors'. ${ }^{56}$

In Novenergia v. Spain, the tribunal found that by abolishing the regulatory framework based on Royal Decree 661/2007, Spain had frustrated the legitimate expectations of the investor. The tribunal disagreed with Spain that a diligent investor would have known of the upcoming changes and that, consequently, it could only expect a 'reasonable rate of return' on its investments. The tribunal noted that the state's assurances that originated from Royal Decree 661/2007 and which stated that the original rate of returns would remain were so 'adamantly clear' that it did not require a 'particularly sophisticated analysis', such as formal legal due diligence. ${ }^{57}$ Also, in the tribunal's view no formal due diligence would have been capable of revealing the regulatory changes that were later enforced by the state. Consequently, the due diligence performed by the investor was considered to be adequate. ${ }^{58}$ As a due diligence report was not disclosed by the investor during the proceedings, it was not possible to assess the content thereof. The state's request to produce this report was also rejected by the tribunal.

In other decisions, the role of the investor's due diligence has been a prominent factor in assessing the legitimacy of an investor's expectations. Tribunals do not indicate any specific requirements regarding the form of the diligence conducted. In terms of its content, however, an investor has to demonstrate that it has conducted an appraisal of the regulatory framework upon which it relies at the time of investment. The scope of such an appraisal differs, however.

For example, in Stadtwerke München and others v. Spain, the tribunal provided that for an investor's expectation to be reasonable, it 'must also arise from a rigorous due diligence process carried out by the investor'. ${ }^{59}$ In this case, the tribunal assessed the investor's due diligence, which was based mostly on communication with governmental and semi-governmental agencies that provided information to suggest that the legal framework would continue to apply. According to the tribunal, these communications did not qualify as a rigorous due diligence process. The tribunal further underlined that 'legitimate expectations must be grounded in the law and not based upon promotional literature about what the law says' ${ }^{60}$ In a similar vein, in Charanne v. Spain the tribunal found that the technical reports of the plants

\footnotetext{
${ }^{56}$ Cube Infrastructure Fund SICAV and others v. Kingdom of Spain, ICSID Case No. ARB/15/20, Award, 26 June 2019, para. 396.

57 Novenergia v. Spain, SCC Case No. 2015/063, Final Award, 15 February 2018, para. 679.

${ }^{58}$ Novenergia v. Spain, SCC Case No. 2015/063, Final Award, 15 February 2018, para. 679.

59 Stadtwerke München and others v. Spain, ICSID Case No. ARB/15/1, Award, 2 December 2019, para. 264.

${ }^{60}$ Stadtwerke München and others v. Spain, ICSID Case No. ARB/15/1, Award, 2 December 2019, para. 287.
} 
in question and the consultancy reports obtained after the investment was made were insufficient to constitute proper due diligence concerning the legal framework. ${ }^{61}$ Comparably, in Antaris v. Czech Republic, the tribunal denied the investor's claim for the protection of legitimate expectations, as there was "no evidence of any real due diligence'. ${ }^{62}$ The tribunal had not found evidence of any legal advice or commissioned due diligence reports. Although the investor referred to legal advice and invoices for this advice, these had not specified the nature of the legal services provided and, as such, were not sufficient to satisfy the required level of due diligence. In Belenergia $v$. Italy, the tribunal found that due diligence reports presented by an investor had not concerned the Italian regulatory risks with regard to the FiTs. ${ }^{63}$ The tribunal emphasised that a "prudent" investor was required to examine Italian photovoltaic (PV) laws ${ }^{64}$ and regulations, which suggest a clear trend toward incentives' reduction'. ${ }^{65}$ Hence, the due diligence conducted by the investor was deemed insufficient.

In Antin v. Spain, the tribunal was satisfied with the extent of due diligence conducted by the investor. In this case, the investor made its investments when several legislative reforms regarding the renewable energy regime had already been made. Nevertheless, the tribunal explained that the state's regulatory changes that had already been adopted prior to the investment mostly affected PV installations. ${ }^{66}$ However, the concentrating solar power (CSP) sector, in which Antin had invested, was impacted to a lesser extent and had continued to receive support from the state's authorities. To this end, the tribunal concluded that Antin had carried out satisfactory due diligence, as it had obtained a legal report, as well as expert opinions and assurances by state representatives that confirmed that the regime for CSP installations was not likely to be modified in the near future. ${ }^{67}$ Consequently, in Antin the tribunal came to the conclusion that due to the state's 2013 measures, e.g. the replacement of the FiTs system with the remuneration system, the essential features of the original regime which was relied upon by the investor had been eradicated and thereby led to a violation of the FET standard. ${ }^{68}$

In several cases, tribunals have determined less stringent requirements regarding the extent of a due diligent inquiry into potential changes to a regulatory regime relied upon by an investor.

\footnotetext{
${ }^{61}$ Charanne Construction v. Spain, SCC Case No. V 062/2012, Final Award, 21 January 2016, para. 366.

62 Antaris Solar GmbH and Dr. Michael Göde v. Czech Republic, PCA Case No. 2014-01, Award, 8 May 2018, para. 432.

63 Belenergia v. Italy, ICSID Case No. ARB/15/40, Award, 6 August 2019, para. 585.

64 The PV sector focuses on the generation of solar photovoltaic energy that captures energy from the sun and converts into electricity, fuels etc.

65 Belenergia v. Italy, ICSID Case No. ARB/15/40, Award, 6 August 2019, para. 587.

66 Antin Infrastructure Services Luxembourg S.à.r.l. and Antin Energia Termosolar B.V. v. Kingdom of Spain, ICSID Case No. ARB/13/31, Award, 15 June 2018, paras. 126-127.

67 Antin Infrastructure Services Luxembourg S.à.r.l. and Antin Energia Termosolar B.V. v. Kingdom of Spain, ICSID Case No. ARB/13/31, Award, 15 June 2018, para. 123.

68 Antin Infrastructure Services Luxembourg S.à.r.l. and Antin Energia Termosolar B.V. v. Kingdom of Spain, ICSID Case No. ARB/13/31, Award, 15 June 2018, para. 560.
} 
In Foresight v. Spain, the tribunal provided that legal advice from a law firm may constitute sufficient due diligence. The tribunal disagreed with the respondent that the due diligence report commissioned by the investor did not include a complete legal analysis of the Spanish regulatory framework and was therefore insufficient. The tribunal found that the investor had been kept informed about the legal developments by its law firm and it is 'reasonable for an investor to assume that its legal advisors would have raised a red flag had they detected any risk of fundamental change to the regulatory regime'. ${ }^{69}$ For OperaFund Eco-Invest v. Spain, the tribunal concluded that two legal opinions provided to a bank that loaned money to an investor were enough to constitute sufficient due diligence. ${ }^{70}$ Even though these legal opinions did not include an assessment of the risks related to the possible changes laid down in Article 44(3) of Royal Decree 661/2007, the tribunal nevertheless found that the investor's due diligence was proper under the circumstances at the time of investment.

\subsubsection{Preliminary Conclusions}

There is no formal legal requirement for an investor to conduct due diligence for the purpose of protecting its legitimate expectations under the FET standard. Nevertheless, tribunals increasingly refer to the importance of this duty, but they provide little guidance in relation to the form that this due diligence should take. Only a small number of tribunals have accepted that some type of formal written legal advice about the potential changes to a challenged regulatory framework was necessary to constitute acceptable due diligence. In other cases, informal sources such as oral legal opinions or general knowledge about a regulatory framework will be sufficient to constitute the required level of due diligence. In terms of the content of a diligent inquiry, tribunals' opinions also differ. In some cases, the tribunal expects an extensive risk appraisal of a specific legal regime relied upon by an investor at the time of investment. In other decisions, moderate due diligence efforts by an investor not specifically directed at an analysis of the disputed legislation has sufficed in demonstrating that the due diligence undertaken was sufficient. In addition to the requirement that concrete efforts to conduct due diligence should be undertaken, some tribunals have examined whether changes in the regulatory framework were foreseeable based on a broader appraisal of a host's state legal and political environment.

The following sub-section will address several factors according to which some tribunals have evaluated the foreseeability of changes that a prudent investor should have known about.

\subsubsection{Foreseeability of Changes at the Time of Investment}

In a number of cases, investment tribunals have elaborated on the type of information about a regulatory framework that should have been taken into account by an

${ }^{69}$ Foresight v. Spain, SCC Case No. 2015/150, Final Award, 14 November 2018.

70 OperaFund v. Spain, ICSID Case No. ARB/15/36, Award, 6 September 2019, para. 487. 
investor when making an investment decision. According to several tribunals, a prudent investor should (1) possess knowledge about the relevant national law and national judicial decisions and (2) consider different sources of information at the time of making the investment. These types of information are addressed below.

3.1.3.1 The relevance of national law and domestic courts In a number of Spanish cases, Spain had argued that an investor should have anticipated the changes to the regulatory framework on the basis of several judgments of the Spanish Supreme Court of 2005, 2006, 2007, 2008 and others. ${ }^{71}$ In referring to these decisions, Spain argued that the changes to the renewable energy regime were predictable and that an investor could not expect more than a reasonable rate of return on its investment. In the judgments relating to electricity operators that were rendered before a special regime was established in 2007, the Supreme Court emphasised that electricity companies do not have 'a "frozen right" that the economic regime that regulates the reception of bonuses remains unaltered'. ${ }^{72}$ In judgments issued after the transformation of the incentive regime, the Supreme Court found that the disputed changes to the regulatory framework were legitimate and were not in violation of the companies' legitimate expectations, legal certainty and the prohibition of retroactivity. ${ }^{73}$

However, tribunals have had different views concerning the Spanish Supreme Court's judgments. In evaluating the investor's due diligence, the tribunal in Charanne v. Spain considered the judgments of the Supreme Court of 2005 and 2006 to be relevant indicators of changes to a regulatory framework laid down by national law. The tribunal emphasised that upon making an appraisal of the Spanish legal system, including the judgments of the Supreme Court, an investor would have known that the Spanish legal system was open to the 'possibility that the system of compensation applicable to photovoltaics could be modified' ${ }^{74}$ Similarly, in Isolux v. Spain, the tribunal noted that the investor possessed specific knowledge, based on the Supreme Court judgments rendered before and after the investment was made, that the feed-in tariffs introduced by the Spanish authorities would not last for the entire lifetime of its investments. ${ }^{75}$ On this basis, the tribunal rejected the investor's claim that its legitimate expectations arising from the stability of the regulatory framework should have been protected. ${ }^{76}$ Along the same lines as Charanne and Isolux, the tribunal in Stadtwerke München and others $v$. Spain stressed the relevance of the Supreme Court decisions in predicting regulatory changes. A judgment of the Supreme Court of 2006 contradicted the argument that a stable regime

\footnotetext{
71 Supreme Court Decision of 15 December 2005, ECLI:ES:TS:2006:6317; Supreme Court Decision of 25 October 2006, ECLI:ES:TS:2006:6317; Supreme Court Decision of 9 October 2007, ECLI:ES:TS:2007:6315 and Supreme Court Decision 9 December 2009, ECLI:ES:TS:2009:8027.

72 Supreme Court Decision of 25 October 2006, ECLI:ES:TS:2006:6317.

73 García-Castrillón (2016), pp. 8-10.

74 Charanne Construction v. Spain, SCC Case No. V 062/2012, Final Award, 21 January 2016, para. 505.

75 Isolux Netherlands, BV v. Kingdom of Spain, SCC Case V2013/153, Award, 17 July 2016, para. 787.

76 Isolux Netherlands, BV v. Kingdom of Spain, SCC Case V2013/153, Award, 17 July 2016, para. 796.
} 
concerning energy operators is immune from revision. ${ }^{77}$ The tribunal also noted that the legislative history of Spain demonstrates that the rates for calculating premiums in the electricity sector had evolved from time to time. Consequently, 'a reasonable and prudent investor would have known of this decision, understood it implications for a contemplated investment, and adjusted expectations accordingly'. ${ }^{78}$

Not all tribunals agreed that Supreme Court judgments were relevant in predicting possible changes to a regulatory framework. In SolEs v. Spain, the tribunal questioned the relevance of the Supreme Court judgments in the assessment of the FET standard under the ECT. In this case, Spain argued that the decisions of the Supreme Court were 'a decisive factual element to configure the legitimate expectation of any investor' and that these judgments clarified that an investor can only expect a reasonable rate of return upon a regulatory transformation of the renewable energy sector. The tribunal took a restrictive approach regarding the role of the Supreme Court's judgments. Firstly, it noted that only judgments rendered before an investment could be of relevance. Secondly, it remarked that the relevant judgments should be approached with caution, as they were based on Spanish law and not the ECT. ${ }^{79}$ Thirdly, the tribunal remarked that the Supreme Court's judgments had little relevance as they did not deal with 'the remuneration of an existing plant that are comparable in significance to the abolition of the Special Regime'. ${ }^{80}$ Based on the aforementioned arguments, the tribunal was not persuaded that 'the case law of the Supreme Court establishes that a prudent investor could have had no legitimate expectation other than that of a reasonable return' ${ }^{81}$ It furthermore noted that even upon such knowledge of the case law, a prudent investor would perhaps only anticipate modest changes to the remuneration regime applicable to an existing plant, but not its complete abolishment. In OperaFund v. Spain and Cube v. Spain, the tribunals completely rejected the relevance of the Spanish Supreme Court's judgments. For example, in OperaFund v. Spain a majority of the tribunal asserted that 'judgments rendered before investment are not relevant for interpretation of Article 44(3) of Royal Decree 661/2007 and cannot be applied thereto by analogy'. No further elaboration was provided. ${ }^{82}$

3.1.3.2 Other sources of information In some decisions, tribunals underline the different sources of information that a prudent investor should have considered before making an investment. For example, in Antaris v. Czech Republic, the tribunal

\footnotetext{
77 Supreme Court Decision of 25 October 2006, ECLI:ES:TS:2006:6317; see: Stadtwerke München and others v. Spain, ICSID Case No. ARB/15/1, Award, 2 December 2019, para. 277.

78 Stadtwerke München and others v. Spain, ICSID Case No. ARB/15/1, Award, 2 December 2019, para. 278.

79 SolEs Badajoz GmbH v. Kingdom of Spain, ICSID Case No. ARB/15/38, Award, 31 July 2019, para. 430.

80 SolEs Badajoz GmbH v. Kingdom of Spain, ICSID Case No. ARB/15/38, Award, 31 July 2019, para. 430.

81 SolEs Badajoz GmbH v. Kingdom of Spain, ICSID Case No. ARB/15/38, Award, 31 July 2019, para. 432.

82 OperaFund v. Spain, ICSID Case No. ARB/15/36, Award, 6 September 2019, para. 491.
} 
labelled the actions of an investor 'opportunistic' because at the time of the investment it was already clear that the feed-in tariffs regime in the Czech Republic was out of balance. ${ }^{83}$ Parallel regulatory changes had taken place and the issue of the tariff deficit was discussed in the press and in a presentation by a Prague law firm that was available to the investor. The tribunal asserted that an 'informed investor who had undertaken proper due diligence' would have known about the upcoming changes on the basis of different sources of information. ${ }^{84}$ Hence, the investor's claim based on the frustration of its legitimate expectations was rejected. In Belenergia v. Italy, the tribunal concluded that an investor that invested between 2011 and 2013 could have clearly observed the trend towards the reduction of incentives. The regulatory measures aimed at the reduction of incentives taken by Italy were clear predictors of upcoming transformational changes. The tribunal concluded that, by conducing adequate due diligence, a 'prudent' investor would have known about the reforms in a renewable energy framework. These reforms had taken place not only in Italy, but all over Europe. According to the tribunal, a " "prudent" investor would have taken into account other European PV incentives schemes' and the fact that 'Italian incentives were higher than in other European countries' ${ }^{85}$

Another factor emphasised by some tribunals is that an investor investing in renewable energy should realize that this sector is highly regulated. Therefore, an expectation that the feed-in tariffs would last for 20 years was not realistic. For example, the tribunal in Charanne v. Spain indicated that a certain level of care is required in such a 'highly regulated [field] as the energy sector, where a preliminary and comprehensive legal framework applicable to the sector analysis is essential to proceed with the investment'. ${ }^{86}$

\subsubsection{Preliminary Conclusion}

Clearly, an awareness about a legal system expressed in Supreme Court judgments has been of importance in many decisions rendered against Spain. Tribunals in several decisions made it clear that the court's judgments are relevant indicators of changes to a regulatory framework laid down by national law. The weight of these judgments in investment cases differs, however. Most tribunals have only accepted judgments rendered before the investment. Some other decisions, such as Isolux, considered a Supreme Court judgment rendered after an investment to be of relevance as well. In cases where the role of due diligence in an overall assessment of legitimate expectations is limited, the judgments of Supreme Courts have

\footnotetext{
${ }^{83}$ Antaris Solar GmbH and Dr. Michael Göde v. Czech Republic, PCA Case No. 2014-01, Award, 8 May 2018, para. 435.

84 Antaris Solar GmbH and Dr. Michael Göde v. Czech Republic, PCA Case No. 2014-01, Award, 8 May 2018, para. 440.

85 Belenergia v. Italy, ICSID Case No. ARB/15/40, Award, 6 August 2019, para. 596.

${ }^{86}$ Charanne Construction v. Spain, SCC Case No. V 062/2012, Final Award, 21 January 2016, para. 507.
} 
had reduced or no significance in assessing the foreseeability of a state's regulatory changes. ${ }^{87}$

Overall, tribunals that tend to place significance on a proper due diligence as a condition for the protection of legitimate expectations appear to attach more relevance to domestic court decisions. In these latter cases, the state's court judgments are a factor indicating the possibility of a change. The same holds true concerning policy developments and the overall situation in the country about which an investor should have sufficiently informed itself by conducting a due diligence inquiry.

\section{The Due Diligence of an Investor as a Balancing Mechanism}

\subsection{The Role of Due Diligence in Balancing Legitimate Expectations and the State's Right to Regulate}

In assessing the legitimacy of an investor's expectations, a number of tribunals have underlined the importance of an investor's own diligent conduct aimed at the preparation and protection of its (future) expectations. ${ }^{88}$ The notion of an investor's due diligence is closely linked to the notion of stability. Recent cases emphasise the growing importance of cautiousness and proper preparation by the investor especially while investing in a highly regulated sector. As tribunals have consistently stated, an investor cannot expect the legal system to freeze. Laws always evolve and will always change. The challenge appears to lie in being able to pinpoint the extent to which a regulatory change is permissible under the FET standard.

In renewable energy cases, the key criterion in the tribunals' assessment of the question of maintaining regulatory stability was whether the change was disproportionate in view of the impact on investors' investments. The tribunals specified that a state's regulatory measure would be considered disproportional when it amounts to a 'sudden and unpredictable elimination of the essential characteristics of the existing framework'. ${ }^{89}$ The tribunals had different views on what constitutes such a sudden elimination. What seems to be a defining factor in assessing the proportionality of the state's measures leading to the transformation of the regulatory framework is how tribunals define the notion of stability.

For example, in Eiser and Antin the tribunals adopted a broad interpretation of the stability requirement stressing that the 'obligation to accord fair and equitable treatment necessarily embraces the obligation to provide fundamental stability in the essential characteristics of the legal regime relied upon by investors in making

\footnotetext{
${ }^{87}$ OperaFund v. Spain, ICSID Case No. ARB/15/36, Award, 6 September 2019, para. 491; Cube Infrastructure Fund SICAV and others v. Kingdom of Spain, ICSID Case No. ARB/15/20, Award, 26 June 2019.

${ }^{88}$ Dupuy and Dupuy (2015), p. 297.

${ }^{89}$ See, for example, Charanne Construction v. Spain, SCC Case No. V 062/2012, Final Award, 21 January 2016, para. 517.
} 
long-term investments'. ${ }^{90}$ Through this prism, these tribunals focused primarily on the impact of the regulatory change for the investors. ${ }^{91}$ Tribunals that have adopted a broad interpretation of stability in relation to the ECT's FET standard tend to attach limited weight to the due diligence of an investor and the specific circumstances in the host state, and primarily consider the impact of the change on the investor's investment. For the tribunals in Charanne, Isolux, Antaris and Stadtwerke München, the state's duty to ensure the stability of the regulatory framework was interpreted more restrictively. In these cases, the tribunals limited the scope of the protection of legitimate expectations by placing emphasis on other elements that were pertinent to the assessment of legitimate expectations, e.g. the legitimacy of public policy objectives, the presence of specific representations, and the due diligence exercised on the part of the investor.

The notion of an investor's due diligence has evolved as one of the relevant considerations in assessing legitimate expectations. Currently, as demonstrated by the case law above, the requirements as to the form and content of due diligence are not clearly defined. The due diligence process is not a formal legal requirement. The central criterion for many tribunals in evaluating an investor's due diligence is whether it has conducted an assessment of the risks concerning a regulatory framework on which it has relied upon at the time of investment. For several tribunals, however, a due diligence report or an opinion that did not contain an assessment of a disputed regulatory regime was still considered to be sufficient. A clear discrepancy between Spanish renewable energy tribunals can be demonstrated based on the example of the role of Spanish Supreme Court judgments. Tribunals that set more elaborate requirements for proper due diligence admitted the judgments of the Spanish Supreme Court as being a relevant source of information on the basis of which an investor could have foreseen the upcoming changes. In contrast, in some cases where due diligence has not been considered to be a requirement for the protection of legitimate expectations, previous Court judgments were also deemed to be irrelevant.

The scope of the required due diligence in the assessment of legitimate expectations remains uncertain. One of the reasons for this is the lack of consistency in the decisions of arbitral tribunals. This is not surprising, considering that the international legal investment system has not been created to "promote uniformity or consistency of either rule-making or rule-interpretation'. ${ }^{92}$ The FET obligation,

\footnotetext{
90 Eiser Infrastructure Ltd. and Energia Solar Luxembourg v. Spain, ICSID Case No. ARB/13/36, Award, 4 May 2017, para. 382; Antin Infrastructure Services Luxembourg S.à.r.l. and Antin Energia Termosolar B.V. v. Kingdom of Spain, ICSID Case No. ARB/13/31, Award, 15 June 2018, para. 532. 'In sum, considering the context, object and purpose of the ECT, the Tribunal concludes that the obligation under Article 10(1) of the ECT to provide FET to protected investments comprises an obligation to afford fundamental stability in the essential characteristics of the legal regime relied upon by the investors in making long-term investments'.

91 Eiser Infrastructure Ltd. and Energia Solar Luxembourg v. Spain, ICSID Case No. ARB/13/36, Award, 4 May 2017, para. 362 and para. 365; Antin Infrastructure Services Luxembourg S.à.r.l. and Antin Energia Termosolar B.V. v. Kingdom of Spain, ICSID Case No. ARB/13/31, Award, 15 June 2018, para. 532.

92 Dolzer and Schreuer (2014) p.15.
} 
interpreted by tribunals in various ways, has developed as an open standard with several evolving components, such as the protection of legitimate expectations. A number of tribunals and commentators ${ }^{93}$ have stressed the importance of predictability and consistency in the assessment of the FET standard as being instrumental to the legitimacy of the system. ${ }^{94}$ In this respect, a consistent requirement for an investor to conduct a formal due diligence process can contribute to a better balance between the notion of stability and the state's right to regulate.

\section{Conclusions}

In this article the role of an investor's due diligence in the context of a FET standard has been analysed. The investor's due diligence is a relevant factor that has been emphasised by tribunals in determining whether the legitimate expectations of an investor give rise to protection under the FET standard. This is especially relevant when an investor's claim for the protection of its legitimate expectations is based on the stability of a regulatory framework. In this respect, tribunals have emphasised that a state has the obligation to provide a certain degree of stability as to the applicable national regulations, which will apply to an investor and its investment. In order to balance the obligation of stability, many tribunals, such as in renewable energy cases, require an investor to exercise proper due diligence and to conduct a risk assessment when considering investing in a host state. The threshold for a violation of legitimate expectations is whether the state's contested regulatory changes were unforeseeable for a prudent investor. ${ }^{95}$ To determine that, tribunals consider: (1) the form and the content of due diligence and (2) the extent of the foreseeability of regulatory changes that can be determined by the efforts undertaken by an investor to assess the risks of change. In terms of the form of a due diligence, tribunals provide no formal requirements to this end. As for the content thereof, a key distinction between tribunals lies in the depth of a diligent inquiry. In several cases, tribunals expect that due diligence includes an appraisal of a disputed regulatory regime relied upon by an investor. Other tribunals have considered due diligence efforts to suffice also when an investor has not analysed the contested regulatory legislation. The extent of the foreseeability of regulatory changes has been assessed by tribunals according to various sources of information available to investors. For example, in a number of cases against Spain, the judgments of the Supreme Court have been

\footnotetext{
93 Bjorklund (2008), pp. 158, 265. The author noted that 'the informal and dispersed regime of investment treaty arbitrations is not well suited to developing a system of formal precedent. Eventually, however, an accretion of decisions will likely develop a jurisprudence constante - a "persisting jurisprudence" that secures unification and stability of judicial activity'.

94 Burlington Resources Inc. v. Republic of Ecuador, ICSID Case No. ARB/08/5, Decision on Jurisdiction, 2 June 2010, para. 100. The tribunal in this case asserted its ambition 'to contribute to the harmonious development of investment law and thereby to meet the legitimate expectations of the community of States and investors towards the certainty of law'.

95 Isolux Netherlands, BV v. Kingdom of Spain, SCC Case V2013/153, Award, 17 July 2016, para. 781.
} 
considered to be important indicators of changes to a regulatory framework, which an investor was expected to take into account while carrying out due diligence.

The case analysis demonstrates that due diligence expected to be performed by investors extends beyond a commercial risk assessment and has important implications for responsible business conduct. For example, the socio-political circumstances in a host state are especially relevant in the context of an investor's due diligence. The latter circumstances influence the general investment climate in the host state. In assessing an investor's expectations, tribunals evaluate the legitimacy of its expectations against the background of the general investment climate. For example, measures taken by a host state to address an energy crisis may frustrate an investor's expectations, especially with regard to the stability of a general regulatory framework. A reversal of a host state's specific representations, or a change to a general regulatory framework, is often a response by the host state to the external changes in economic or socio-political circumstances. Therefore, in assessing whether an investor's expectations must still be protected in such a situation, tribunals have indicated that the expectations 'must rise to the level of legitimacy and reasonableness in light of the circumstances'. ${ }^{96}$ In this regard, a responsible investor's conduct is one of the criteria in the evaluation of legitimacy. Responsible conduct involves an identification of different types of risks, including changes in energy policy, following mitigation efforts, e.g. a decision not to invest in a host state. The investor is expected to commission a due diligence report that also includes an assessment of a general regulatory framework. That may include a detailed appraisal of legislation that is relevant to an investment, a state's political dynamics including the human rights situation, public opinion etc.

This type of due diligence to some extent corresponds with the human rights due diligence framework that requires a company to 'identify, prevent, mitigate and account for' the adverse human rights impacts of its own activities. ${ }^{97}$ However, an investor does not focus on human rights issues per se before carrying out a due diligence inquiry into a regulatory framework of a host state. It may however detect possible human rights risks that are harmful to its investments. And by neglecting to take these human rights risks into account, an investor risks undermining its claim for protection under legitimate expectations. The example in this respect is the Urbaser $v$. Argentina case, where the tribunal emphasised, in assessing the FET claim, that an investor was expected to be aware of the objective of the state 'to ensure the population's health and access to water' according to its Constitution. ${ }^{98}$ This case demonstrates that specifically when an investor operates in a highly sensitive industry such as water and sanitation services, a due diligence assessment, including possible human rights impacts, is an essential part of appraising a host state's regulatory framework. Therefore, the investor's due diligence has the

\footnotetext{
96 Saluka Investments BV v. Czech Republic [2006] UNCITRAL Arbitration Partial Award, 17 March 2006, para. 304.

97 UN Guiding Principles on Business and Human Rights (2011).

98 Urbaser S.A. and Consorcio de Aguas Bilbao Bizkaia, Bilbao Biskaia Ur Partzuergoa v. The Argentine Republic, ICSID Case No. ARB/07/26, Award, 8 December 2016, para. 622.
} 
potential to promote responsible business conduct. This however requires clarification and consistency concerning the scope of an investor's due diligence in investment decisions.

Open Access This article is licensed under a Creative Commons Attribution 4.0 International License, which permits use, sharing, adaptation, distribution and reproduction in any medium or format, as long as you give appropriate credit to the original author(s) and the source, provide a link to the Creative Commons licence, and indicate if changes were made. The images or other third party material in this article are included in the article's Creative Commons licence, unless indicated otherwise in a credit line to the material. If material is not included in the article's Creative Commons licence and your intended use is not permitted by statutory regulation or exceeds the permitted use, you will need to obtain permission directly from the copyright holder. To view a copy of this licence, visit http://creativecommons.org/licen ses/by/4.0/.

\section{References}

Bank of Spain (2017) Report on the financial and banking crisis in Spain, 2008-2014. https://www.bde. es/f/webbde/Secciones/Publicaciones/OtrasPublicaciones/Fich/InformeCrisis_Completo_web_ en.pdf. Accessed 5 Nov 2019

Bjorklund A (2008) Investment treaty arbitral decisions as jurisprudence constante. In: Picker C et al (eds) International economic law: the state and future of the discipline. Hart Publishing, Oxford, pp $265-280$

Bonnitcha J (2014) Substantive protection under investment treaties: a legal and economic analysis. Cambridge University Press, Cambridge

Brown C (2009) The protection of legitimate expectations as a 'general principle of law': some preliminary thoughts. Transnatl Dispute Manag 6(1):1-10

Dolzer R, Schreuer C (2014) Principles of international investment law. Oxford University Press, Oxford

Dupuy F, Dupuy P-M (2015) What to expect from legitimate expectations? A critical appraisal and look into the future of the 'legitimate expectations' doctrine in international investment law. In: Raouf MA et al (eds) Festschrift Ahmed Sadek El-Kosheri: from the Arab world to the globalization of international law. Kluwer, Alphen aan den Rijn, pp 273-298

García-Castrillón C (2016) Spain and investment arbitration: the renewable energy explosion. InvestorState Arbitration Series, GIGI, Paper No 17

Klager R (2011) Fair and equitable treatment in international investment law. Cambridge University Press, Cambridge

Laird I et al (2015) International investment law and arbitration: 2014 in review. In: Bjorklund AJ (ed) Yearbook on international investment law and policy 2013-2014. Oxford University Press, Oxford, pp 65-85

Levashova Y (2019) The right of states to regulate in their public interest and the right of investors to receive fair and equitable treatment 2019. Kluwer arbitration series. Wolters Kluwer, Alphen aan den Rijn

Matteotti M, Payosova T (2017) The role of fair and equitable treatment standard: regulatory coherence for trade and investment in renewable energy. In: Cottier T, Espa I (eds) International trade in sustainable electricity. Cambridge University Press, Cambridge, pp 428-456

Paulsson J (2016) Can 'legitimate expectations' ever be 'rights'? https://lex.jotwell.com/can-legitimate -expectations-ever-be-rights/. Accessed 1 Sep 2019

Potestà M (2013) Legitimate expectations in investment treaty law: understanding the roots and the limits of a controversial concept. ICSID Rev 28(1):88-122

Selivanova Y (2018) Changes in renewables support policy and investment protection under the Energy Charter Treaty: analysis of jurisprudence and outlook for the current arbitration cases. ICSID Rev 33(2):433-455

Sornarajah M (2015) Resistance and change in the international law on foreign investments. Cambridge University Press, Cambridge 
Sureda AR (2012) Legitimate expectations, risk and due diligence. In: Sureda AR (ed) Investment treaty arbitration: judging under uncertainty. Cambridge University Press, Cambridge, pp 76-96

Valenti M (2014) The protection of general interests of host states in the application of the fair and equitable treatment standard. In: Sacerdoti G et al (eds) General interests of host states in international investment law. Cambridge University Press, Cambridge, pp 26-57

Vandevelde K (2010) A unified theory of fair and equitable treatment. NY Univ J Int Law Policy 43(1):43-106

Viñuales J (2017) Investor diligence in investment arbitration: sources and arguments. ICSID Rev 32(2):346-370

Wongkaew T (2015) The transplantation of legitimate expectations in investment treaty arbitration: a critique. In: Lalani D, Lazo R (eds) The role of the state in investor-state arbitration. Brill Nijhoff, Leiden, pp 69-102

Publisher's Note Springer Nature remains neutral with regard to jurisdictional claims in published maps and institutional affiliations. 